\title{
Non-Discursive Knowledge and the Construction of Identity Potters, Potting and Performance at the Bronze Age Tell of Százhalombatta, Hungary
}

\author{
Sandy Budden \& Joanna Sofaer
}

\begin{abstract}
This article explores the relationship between the making of things and the making of people at the Bronze Age tell at Százhalombatta, Hungary. Focusing on potters and potting, we explore how the performance of non-discursive knowledge was critical to the construction of social categories. Potters literally came into being as potters through repeated bodily enactment of potting skills. Potters also gained their identity in the social sphere through the connection between their potting performance and their audience. We trace degrees of skill in the ceramic record to reveal the material articulation of non-discursive knowledge and consider the ramifications of the differential acquisition of non-discursive knowledge for the expression of different kinds of potter's identities. The creation of potters as a social category was essential to the ongoing creation of specific forms of material culture. We examine the implications of altered potters' performances and the role of non-discursive knowledge in the construction of social models of the Bronze Age.
\end{abstract}

Tension between the discursive and the material is a key issue for archaeologists. Archaeologists often tend to describe social relations in terms of discursive knowledge, defined by Foucault (1969) as the symbolic, cognitive and abstract, and often clearly articulated in archaeological writing through, for example, ideas about material culture as text, symbolism and iconography (e.g. Hodder 1982). Yet we excavate things, not discourse. Ingold (2007) has recently argued that an emphasis upon the discursive tends to ignore the material qualities of things. An exploration of non-discursive knowledge or know-how is therefore important if we are to understand how materiality is articulated.

Non-discursive knowledge is performed body knowledge. Distinct from, if linked to, discursive knowledge (Hacking 2004; Gardner 1999; 1993), it is the transference of information understood at a cognitive level in terms of the principle of what needs to be done, into the practical action of how things are, or should be, done (Anderson 1982; 1983; 1987; Knappett 2005). In other words, the distinction between discursive and non-discursive knowledge is the difference between 'saying' and 'doing' (Hodder 1993, 255). A classic example often given to illustrate the difference between these two types of knowledge is learning to ride a bike (Knappett 2005, 5). It is possible to understand the principles of how to ride a bike without actually being able to perform the task. Only with repeated practice can one cycle without constant reference back to the articulation of those principles.

The distinction between discursive and nondiscursive knowledge also reflects a difference in scale which Ian Hacking (2004) has described as 'top down' vs 'bottom up'. Discursive knowledge is the 'top down' scale exemplified by Foucault's use of the discursive to think about overarching social institutions (Foucault 1969). Non-discursive knowledge is the 'bottom up' scale represented by the work of sociologist Erving Goffman on contextually specific performances of individuals and their face-to-face interactions (Goffman 1959; 1967; Hacking 2004). Thus, while a tendency to separate discussions of discursive and non-discursive knowledge has been

Cambridge Archaeological Journal 19:2, ???-?? @ 2009 McDonald Institute for Archaeological Research doi:10.1017/S09597743090000?? Printed in the United Kingdom. 
seen as a reflection of a Cartesian separation between the thinking body and doing mind (Knappett 2005, 5), the relationship between the two forms of knowledge is primarily a question of the articulation between social institutions and actions of the individual. The distinction between discursive and non-discursive knowledge reiterates the difference between structure and agency (Hacking 2004).

In the social sciences, including anthropology and sociology, the construction of identity through situated social practice and the performance of nondiscursive knowledge have long been seen as critical to the construction of social categories (Chalkin \& Lave 1996; Goffman 1959; Latour 2005; Lemonnier 1992a; 1990; Mauss 1935; Pfaffenberger 1999; 1992; Singleton 1998a). In particular, the education of craftspeople generates identity in relation to their communities of practice (Rogoff 1990; Singleton 1998a). In archaeology, however, despite a range of theoretical frameworks that allow us to move from objects to discussions of social life, we have been slow to investigate the role of non-discursive knowledge in bringing material culture into being, and the ways in which the making of things may be implicated in social relations. In 1992 Hodder remarked that we have very little idea of how know-how or practical knowledge works and how it relates to the more general and abstract levels of meaning' (Hodder 1992, 206). Today, the relationship between discursive and non-discursive knowledge in relation to identity formation remains something of a persistent problem (Dobres 1999; Knappett 2005).

Knappett $(2005,8)$ argues that an archaeological focus on discursive knowledge, where through the linguistic metaphor for material culture the 'saying' is transformed into symbolism, results in a problematic conflation of signification with communication. This is not, however, the only difficulty arising from this situation. A further issue is a tension between theory and method in archaeological practice caused by a mismatch between the ways that people are theoretically understood to be actors but methodologically accessed through associations between people and material culture, resulting in rather static interpretations. In other words, the construction of identity in archaeological contexts has long been explored through associations between material culture and individuals (in the case of craftspeople, for example, the identification of metalworkers on the basis of associations between people and suites of objects in mortuary contexts) (cf. Butler 1966; Shell 2000). Such analyses highlight a state, category or end point, rather than a process of 'becoming' or identity formation. They stress the role of material culture as symbolic capital which confers identity upon the user or owner, instead of the actions of people in constructing their identities. Hence they often imply that the identity of these individuals resides outside the body in the symbolism of objects rather than in the bodies of people (Sofaer 2006a). A frequent emphasis on discursive knowledge through a focus on symbolism in interpretative schemes, without its counterpart of non-discursive knowledge, leads to an archaeological emphasis on being rather than becoming through doing. In this sense archaeological interpretations tend to be akin to photographic stills, rather than moving images.

Thus while archaeologists are often very good at describing and categorizing objects in social, technical or typological terms they have been less active in exploring the social reverberations of the production process itself, both in terms of the physical relationship between craftspeople and their materials, and the interaction between craftspeople and people who must have seen them at work - what might be called their audience. There is a gap in archaeological interpretations between the making of material culture and the making of people. One way forward in this dilemma is to explore the role of non-discursive knowledge in relation to discursive knowledge, rather than treat them as opposite and incompatible notions. Discursive and non-discursive knowledge are complementary as both are needed in order to understand 'the making up of people' (Hacking 2004). The 'making up of people' is articulated through the interactions between abstract classifications and concrete actions. In other words, the identities of people in terms of classifications such as gender, age, status or professional standing are constructed in relation to a set of discursive criteria which are socially understood and against which the performance of concrete non-discursive actions of individuals can be compared (Hacking 2004).

In this article we want to explore the construction of social identity of prehistoric craftspeople through the non-discursive knowledge involved in the production of one particular form of material culture: pottery. Potting is a very physical process that requires the potter to engage bodily with his or her clay and tools. Potters and potting therefore form an example of the ways in which non-discursive knowledge is articulated through the repeated enactment of bodily performance. Furthermore, the nature of clay means that these performances can be investigated through their material traces in the ceramic record.

Our case study focuses on potters and pottery from the Bronze Age tell at Százhalombatta in Hungary. Our key question is, 'how are potters at Százhalombatta created'? In other words, how do 
skill and social identity come into being, and how are these related? In addressing this, our article deals with two aspects. Following a brief introduction to the pottery from Százhalombatta, we begin by examining the ways in which potters' identities were constructed through the process of potting. We then explore the ways in which their identities were constructed through interaction with their audience, and the ways in which they conformed (or not) to expectations of their craft. In tracing the material articulation of non-discursive knowledge in the ceramic record, we examine the implications of this approach for the construction of social models of the European Bronze Age. It is particularly appropriate to explore the role of non-discursive knowledge in identity formation in a complex nonliterate society (Earle 2002; Kristiansen 1998) where non-discursive knowledge must have been of critical importance to the creation of categories of people.

\section{Pottery at the Bronze Age Tell at Százhalombatta, Hungary}

The site of Százhalombatta is situated on the right bank of the Danube, $30 \mathrm{~km}$ south of Budapest (Fig. 1). It is one of the largest and best preserved Bronze Age temperate tell settlements in central Europe being 200 $\mathrm{m}$ by $100 \mathrm{~m}$ in area, excluding the south and southwest parts of the site which may represent up to one third of the original area and which were destroyed during clay extraction by a local brick factory and by erosion by the River Danube (Poroszlai 2000). The site has been the subject of three excavation campaigns. The first in 1963 by Tibor Kovács of the Hungarian National Museum (Kovács 1969), the second in 1989-93 by Ildiko Poroszlai of the Matrica Museum (Poroszlai 2000; 1996), and most recently from 1998 an on-going international excavation (the SAX Project), involving teams from the Matrica Museum, and universities of Gothenburg, Cambridge and Southampton. ${ }^{1}$ Excavation has focused on domestic contexts and work is revealing a detailed picture of settlement structure and architecture; all the material discussed in this article comes from domestic contexts, in particular the inside of houses. Finds from the site include pottery, metalwork, moulds, loom weights, phytoliths, worked wood, bone and stone, faunal and human remains. Of these, pottery is the most abundant with almost 1.7 tonnes recovered since 1998, including many complete or partially complete vessels; 292 whole vessels or featured sherds were examined for the analysis presented in this article.

The majority of the rich ceramic assemblage dates from 2000-1500/1400 BC, spanning the Early

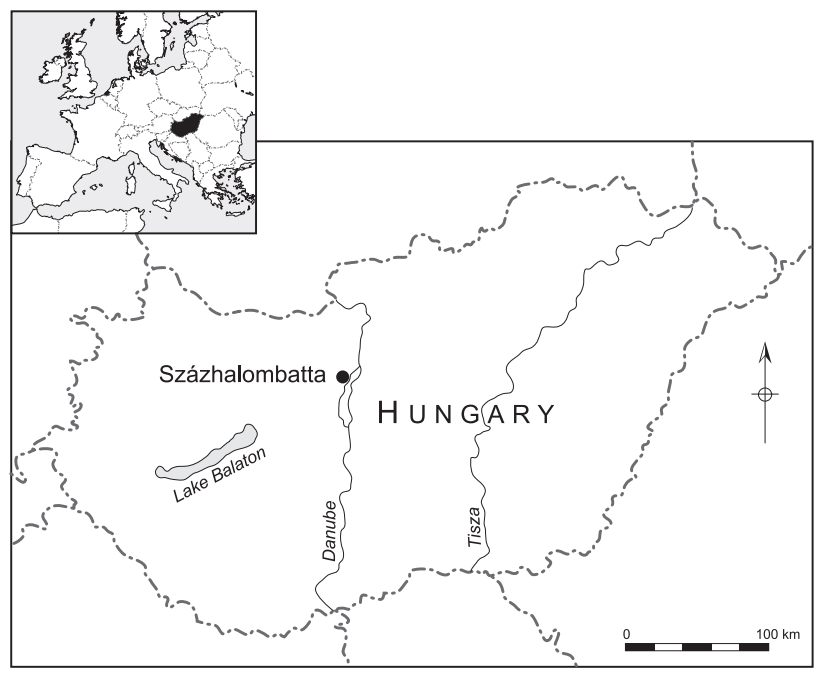

Figure 1. Map of Hungary showing the location of Százhalombatta.

Bronze Age classic Nagyrév (Szigetszentmiklós) to late Nagyrév (Kulcs) transition, through the following Middle Bronze Age Vatya tradition (Vatya I-III) and Vatya-Koszider phase at the end of the Middle Bronze Age, to the start of the Late Bronze Age (equivalent to the Tumulus phase elsewhere in Europe). There follows a hiatus in occupation at the site until the Urnfield period. From the Early Bronze Age through to the end of the Middle Bronze Age there is a wide range of vessels. While basic types such as cups, bowls, jugs and urns are present throughout and form the core of the assemblage, the range and elaboration of vessels within each of these categories changes, resulting in complex typological variation (Budden 2007; Vicze 2001). The transition from the Early to the Middle Bronze Age sees an increase in the range of forms within individual vessel types as well as the introduction of new types (Fig. 2), traditionally understood as a result of the shifting cultural traditions of the Nagyrév and the influence of contemporary Kisapostag communities and the emergence of the Vatya tradition (Bóna 1992; 1975; Poroszlai 2003; 2000; Vicze 2001). Vessel forms include small cups, sieves, fish-dishes, deep domestic (cooking) bowls, cooking jar forms, storage vessels, small bowls (for eating), storage vessels, fineware bowls and jugs, urns, ember covers, and miniature forms that replicate the assemblage as a whole. In the Koszider phase at the end of the Middle Bronze Age the range of vessel forms decreases, but there is noticeable elaboration and exaggeration of existing forms (Budden 2007; Sofaer 2006b; Vicze 2001). Although there are some imported Middle Bronze Age ceramics at the site, 


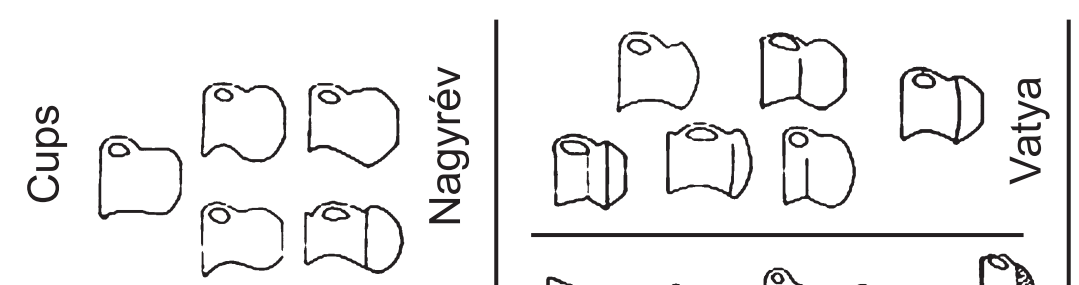
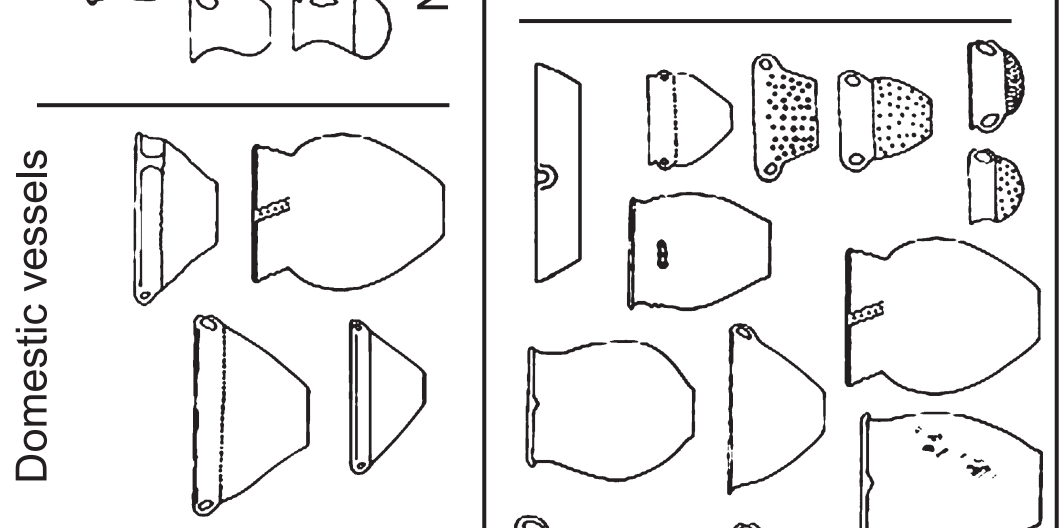

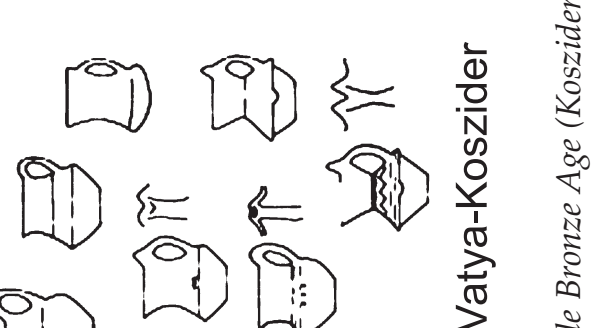

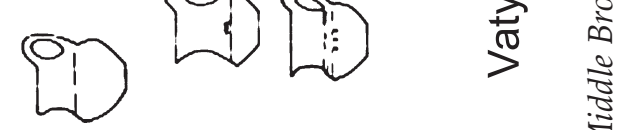
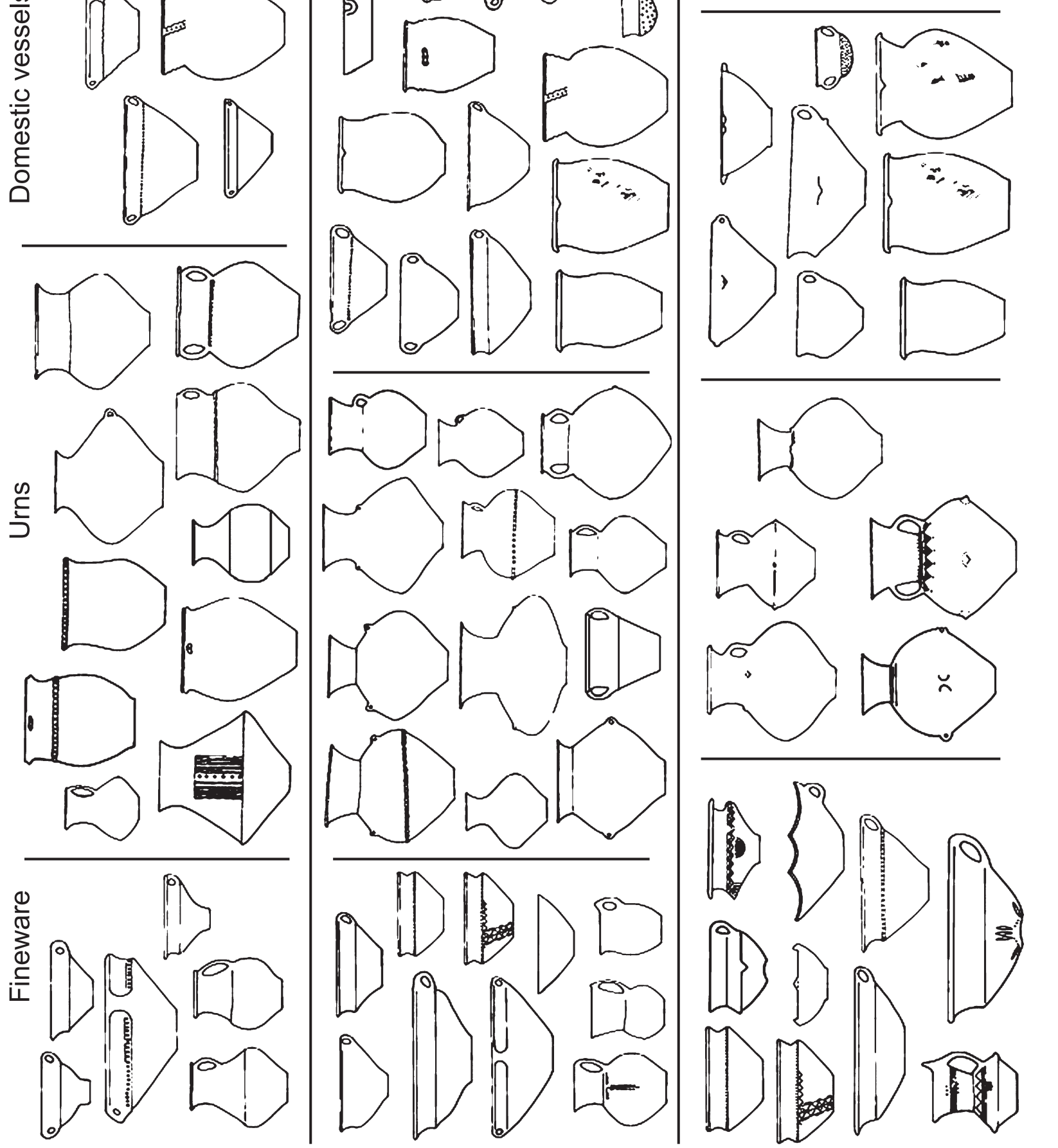

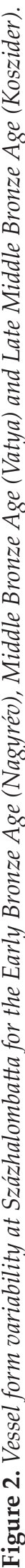


notably from the neighbouring Incrusted Pottery Culture, these are clearly identifiable on the basis of their distinctive decoration. The Vatya pottery from Százhalombatta has a distinct quality and style, notably in its finewares (Budden 2007), while recent petrological and geochemical work has demonstrated that the overwhelming majority of the pottery at the site is locally made (Kreiter et al. 2007).

The wide range of vessel types at the site represents an outstanding array of technical complexity engaged with by potters. For example, Nagyrév jars with pedestal bases and fine-walled Koszider jugs with exaggerated angular tripartite profiles, anza lunata handles, complex embellishments and a high burnish, require extraordinary technical competency to make. To fire these successfully is also difficult as the angularity and additions in the form of bases, bosses or anza lunata handles are known to induce thermodynamic stress (Braun 1983; Rice 1987; Rye 1981). Large storage vessels or urns with measurements ranging from $22 \mathrm{~cm}$ up to $72 \mathrm{~cm}$ in height with rim diameters ranging from $7.5 \mathrm{~cm}$ to $41 \mathrm{~cm}$ also with complex tripartite morphologies and exaggerated additions of lugs, handles and complex decoration are another key element of the Százhalombatta assemblage. These vessels require particular investment of skill as the pottery form grows in height and width. Any error made will become exaggerated as the vessel grows in stature and even small mistakes may compromise a successful outcome. Inexperienced handling of the clay may cause slumping, warping and thus cracking as the pot starts to dry out or in the firing process (Caiger-Smith 1995; Rice 1987).

The degree of skill deployed in the production of individual vessels reflects the acquisition of non-discursive knowledge and can be assessed by scoring individual technological variables against the expected outcome for a given vessel type. So, for example, if like domestic wares a particular vessel type is repeatedly produced to have thick, even walls then this is the expected or correct outcome and would be scored as good. If, however, the wall thickness was extraordinarily variable or thin it would score as poor. Conversely, if the wall thickness of a fineware Koszider jug was excessively thick, lumpy or uneven then this variable would score as 'poor' for that vessel form. It is essential to stress that this is not a measurement of aesthetics but of technical competence exercised for any given technological variable, and that these variables are not ranked in any hierarchy. Thus, for example, decoration and wall thickness are evenly weighted. The score given to any aspect of a given vessel reflects the degree of non-discursive knowledge of the potter; where poor execution of skill occurs potters have not yet acquired the finesse of body actions characterized by skilfully made pots. In combination, the range of technological variables represents the proposed outcome and characteristics that should be encompassed within a single vessel type. ${ }^{2}$

The skill needed to produce some of the more complicated vessels argues for specialist production of a number of forms (Budden 2007). Finewares, in particular, were desirable objects implicated in display and prestige (Sofaer 2006b; Vicze 2001). Furthermore, potters and other craftspeople may have held distinctive positions within the social hierarchy (Sofaer $2006 \mathrm{~b}$ ). The creation of potters as a social category was therefore essential to the ongoing creation of specific forms of material culture and to the perpetuation of stratified social relations.

\section{Becoming a potter at Százhalombatta: the acquisition of non-discursive knowledge}

The morphologically complex and large forms found within the Százhalombatta assemblage represent the work of accomplished potters capable of meeting the challenge of producing technically complex forms that accord with local ideas of what constitutes appropriate pots. The skill required to make these vessels comes into being over time through the acquisition of learned and practised non-discursive knowledge. The way in which this happens, and the reverberations of the production process in terms of the relationship between the acquisition of non-discursive knowledge, the skilled making of material culture, and the construction of social identity, can be understood by reference to the work of ethnologist and sociologist Marcel Mauss (1935; 1947).

Mauss advanced the concept of the 'homme total' where man is himself a tool; a notion re-explored by Ingold (1990; 1998; 1999; 2000) and Gamble (2007). As Mauss himself put it, 'the body is man's first and natural instrument. Or more accurately ... man's first and most natural technical object, and at the same time technical means, is his body' (Mauss 1935, 83). He famously suggested the idea of 'techniques $d u$ corps' or 'techniques of the body', placing technique or 'traditional effective acts' at the centre of his notion of the 'homme total' (Mauss 1935). In his essay of 1935 on The Techniques of the Body, Mauss points out, for example, that although the capacity to walk is universal, people in different cultures are brought up to walk in very different ways. For Mauss, technique was the bedrock of society. Culturally contingent learnt human actions underpinned technology because they are at the core 
of how things are made. The study of human actions thus provides a means through which to understand social life. Indeed, for Mauss technology was the scientific study of technique, while technique was about the conjoined social and physical performance of every daily activity by the human body (Mauss 1947). The repetition of technique was central to Mauss's idea of total human action; the more frequently the necessary non-discursive knowledge is carried out, the more developed the 'techniques of the body' will become and the greater the execution of skill, both in terms of the degree of skill invested and the speed of execution. The acquisition of non-discursive knowledge is thus intimately connected to human ontogeny. A nice example of this is given by Sturt (1923) where he describes how it is not cognitive reasoning or scientific planning that allows the apprentice to master the many tasks associated with the craft of the nineteenthand early twentieth-century wheelwright but rather the development of non-discursive knowledge:

A wheelwright's brain had to fit itself to this [the tasks of the wheelwright] by dint of growing into it, just as his back had to fit into the suppleness needed on the saw pit, or his hands into the movements that would plane a felloe 'true out o' wind'. Science? Our two-foot rules took us no nearer to exactness than the sixteenth of an inch: we used to make or adjust special gauges for the nicer work; but very soon a stage was reached when eye and hand were left to their own cleverness, with no guide to help them (Sturt 1923, 19).

The chaîne opératoire was key to Mauss's exploration of the homme total, being the means by which he suggested that techniques of the body might be traced. Although recent re-appraisal of the work of Mauss has seen a desire to reintroduce his approach to the study of human history (Dobres 2000; Edmonds 1990; Gamble 2007; Ingold 2001; Schlanger 2006; 1998; Toren 1999), on the whole, archaeological engagement with the chaine opératoire has frequently followed the version of the concept proposed by Mauss's student, André Leroi-Gourhan (1943; 1945). Leroi-Gourhan made a direct separation between man and tool (Dobres 2000; Edmonds 1990), shifting the emphasis towards the study of objects and away from non-discursive knowledge. This revised version of Mauss's vision offered archaeology a useful way of exploring technical sequences, but narrowed and undermined Mauss's original concept which placed education as the dominant force in the adoption of techniques of the body (Dobres 2000; Edmonds 1990; Mauss 1935). While descriptions of production sequences engendered by the chaine opératoire have been useful in demonstrating the way in which technical sequences unfold (Dobres \& Hoffman 1994, 214), they have often failed to provide a platform for understanding the broader social conditions under which procedures were implemented, or how such knowledge was initiated, sustained or transformed (Edmonds 1990, 58; Knappett 2005, 5). Similarly, discussions of 'motor habit patterns' (e.g. Arnold 1985) have not pursued what these mean, either in terms of social relations or the creation of identity. A tendency to follow LeroiGourhan's version of the chaine opératoire in modern archaeology has, therefore, frequently resulted in failure to see that what should sit beneath the chaine opératoire is an understanding of socially and culturally adopted learning strategies, and the acquisition and deployment of skill generated by these, through which craftspeople as well as material categories are created.

Where any level of skill is acquired, the repeated enactment of non-discursive knowledge eventually results in the embodiment of a suite of physiological actions to the extent that it literally changes the neurology, musculature or skeleton (Anderson 1987; 1983; 1982; Gardner 1993; Goffman 1959; Hacking 2004; Ingold 1993; Mauss 1935). As Tim Ingold (1993, 470) puts it, 'Biologically therefore, English speakers are different from Japanese speakers, cello players are different from sitar players, lasso throwers are different from archers'. Similarly, Christina Toren's (1994; 1999) work on child cognition and the learning of hierarchy in Fiji discusses mind as a material phenomenon since learning how to behave in an appropriate manner involves changes to the mind and body as physical and inseparable entities. This perspective, strongly influenced by Mauss, is allied to an increasing number of workers in a range of fields including sociology, psychology and neurology, who have argued that not only the body but also the brain is a product of its relation to culture (Dickens 2001; Keating \& Miller 1999). Mauss's vision of the 'homme total', with its link between the physical creation of self through the generation of techniques of the body and the construction of identity, has also provided inspiration for recent theoretical approaches to osteoarchaeology (Sofaer 2006a).

Since the acquisition and exercise of non-discursive knowledge has material repercussions for the human body, it must be argued to be far more than superficial habit. In the case of potters, they are literally created in the most physical sense through the act of potting. This means that the acquisition of non-discursive knowledge is therefore not only about the production of objects, but also about the production of self identity. The technical actor 'creates 
and at the same time he creates himself; he creates at once his means of living, things purely human, and his thought inscribed in these things' (Mauss 1927, in Schlanger 2006, 20). It is important to note here that the physiological nature of non-discursive knowledge means that it is impossible to unlearn skill. Even where a skilled potter or other craftsperson produces less than their 'best' work they will still incorporate a degree of procedural knowledge not achievable by a practitioner who has not fully acquired the proper suite of actions to create a successful outcome (Budden 2008, 10). An example of this in a hand-made pot, such as those found at Százhalombatta, would be the difference between a skilled potter producing a pot in a hurry but maintaining the procedural skill to correctly 'bond' successive coils or slabs of clay and a novice potter who has not yet learnt to ensure that clay is of the correct consistency for this process to be successfully completed. There is, however, a caveat to this. The full acquisition of non-discursive knowledge can only happen where an aptitude exists. Not every potential participant will have the aptitude to acquire a specific skill; what one person can do, another cannot. Crown (1999), for example, argues that people who do not wish to pot or cannot pot, do not pot. Hodder $(1991,88)$ makes a similar same point regarding the decoration of calabashes.

Once learnt, it is not an easy matter to alter technique. This does not mean, however, that previous skills cannot be overlain with new or more advanced ones. Mauss $(1935,83)$ stressed the importance of the adaptation of technique to changing circumstances, and saw the ways that techniques alter as the result of a changing relationship between person and society. Given that the acquisition of non-discursive knowledge and the expression of technique is linked to the construction of the self, it follows that changes to technique may also impact on the production of identity. New or changing techniques can therefore be understood not only as a key means by which innovation or reinvention of material categories occurs, but also a means by which people can move between social categories and attain a range of social identities over time.

\section{Tracing technique at Százhalombatta}

As well as affecting the human body, techniques leave traces on objects. Detailed ethnographic descriptions of the body actions of craftspeople involved in the production of different forms of material culture have been employed to reconstruct the chaine opératoire in its original meaning (Gelbert 1999; Gosselain 1999; 2000), and can be mapped back to archaeological objects (e.g. Budden 2008; Dobres 1999; 2000; Dobres \& Hoffman 1994; Lemonnier 1992a,b; Pigeot 1991; 1990; Roux 1990; Roux \& Blasco 2000; van der Leeuw et al. 1991). In the particular case of pottery, clay is a plastic additive medium so the actions of potters can be traced in the ceramic record. Producing different vessel types requires different suites of bodily actions from the potter who has to engage with varying technical requirements and tools. Techniques of the body are materially expressed as clear repeated patterns common to potters working with an understood repertoire of vessel types who understand the 'rules' surrounding the correct ways to make specific socially acceptable vessel types.

To examine the acquisition of non-discursive knowledge at Százhalombatta and the construction of potters' identities, we therefore need to look at technical actions embedded in the pots. The Százhalombatta assemblage is highly constrained by very clear rules surrounding the production of well-defined pottery types and decorations. This means that each vessel type will have a range of explicit technological signatures that can be identified through close observation of individual vessel types.

At Százhalombatta this can be illustrated by looking at one common vessel type which conforms to very specific parameters: the fineware Koszider jug (Fig. 3). Koszider jugs vary in size from $90 \mathrm{~mm}$ to $195 \mathrm{~mm}$ in height but they all have a common series of procedures involved in their production. These include: levigating the clay, wedging the clay, coiling a complex tripartite form, using fine motor control and scraping actions to produce a wall thickness of 2-4 $\mathrm{mm}$, manipulating the production of a push-through peg handle (Sofaer 2006b) with a complex anza lunata form springing from the vessel rim, burnishing the pot to a high sheen, manipulating tools to produce complex chevron and dot decoration, the manipulation of appropriate fuel (cf. Sillar 2000), and fire-setting in order to create a reduction fired finish.

To make a Koszider jug means that a predetermined series of learnt bodily actions must be followed which result in the production of a recognized form of material culture. Since skill is acquired in a cumulative manner, the more frequently a required procedure is carried out, the more competent a potter will become. It is therefore possible to trace the process of skill acquisition and the different degrees of skill manifested in material culture through the identification of bodily actions that are either poorly or skilfully performed. For example, each of the pairs of vessels in Figure 4 are essentially the same form but the ones shown on the right are much more skilfully made 


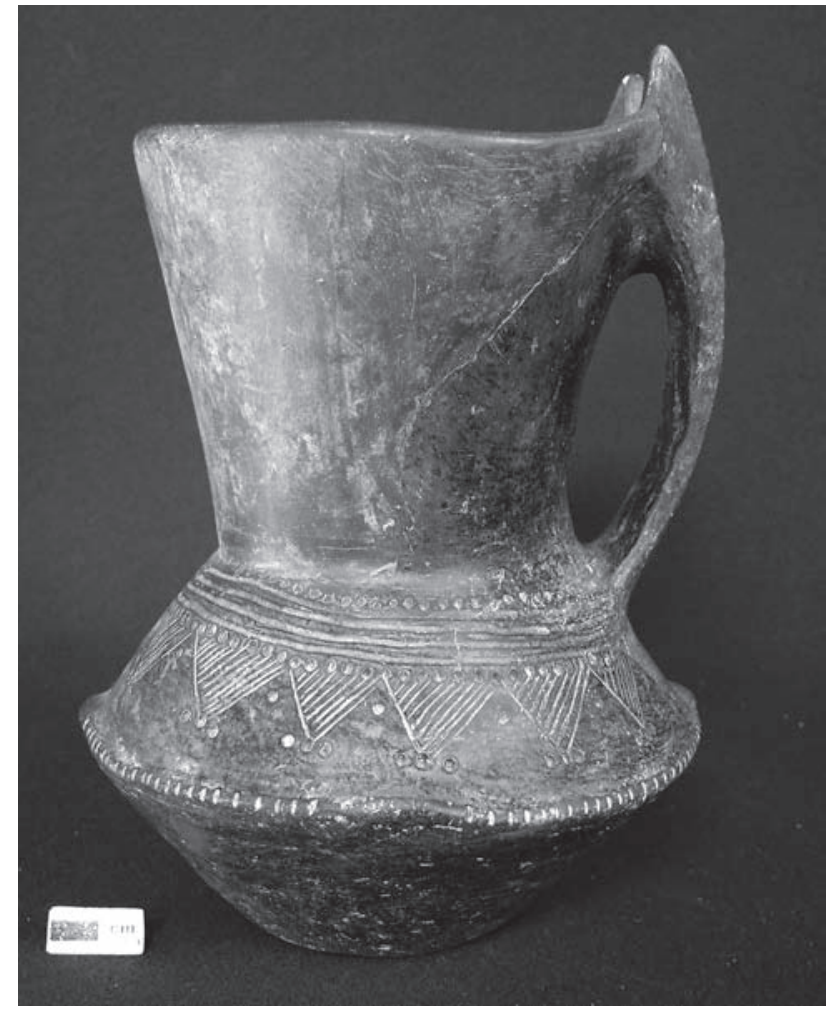

Figure 3. Fineware Koszider jug from Százhalombatta.

than those shown on the left. In other words, the pots on the right have been produced by potters who have already acquired relevant non-discursive knowledge enabling skilled production of the vessels. By contrast, the potters of the vessels on the left have not acquired the same level of non-discursive knowledge as they have not yet mastered all the skills involved in the production of these vessel types. This difference in skill implies the existence of different forms of identities for the different potters linked to experience (such as master and apprentice) and/or aptitude.

Potters with different identities may also collaborate together to make individual vessels (Crown 2007). Especially in settings with internal hierarchies such as workshops with structured systems of apprenticeship, individuals may be assigned particular tasks based on factors including gender, age or experience (Crown 2007; David 1990; Kamp 2001; Kramer 1985). Given the repetitive nature of non-discursive knowledge and the way in which it brings about pre-determined vessel forms, it is possible to investigate the institutional organization of pottery production using the scoring method for identifying skill described above to track patterning in skill investment for a suite of technological variables. Each variable represents different body

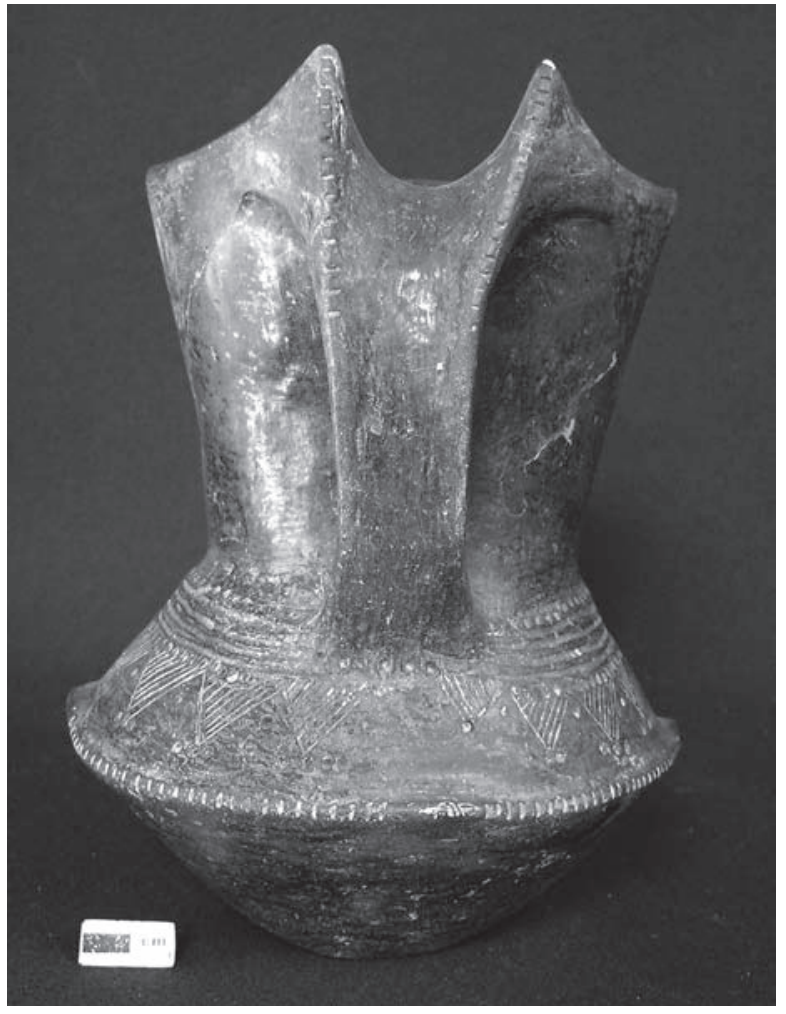

techniques.

The results of analysis exploring this phenomenon in relation to domestic vessels are shown in Table 1 and Figure 5. If all aspects of vessel manufacture are of equal difficulty, and pots are made by single potters, then we might expect to find a relatively homogeneous expression of skill for different elements of the production of a single vessel. What we find, however, is the differential investment of skill between technological variables. For example, rim deviation on the horizontal plane displays significantly less skill than almost all other variables, while wall thickness, rim deviation on the horizontal plane, and profile symmetry display less skill investment than manufacturing (the variable indicating the proficiency of vessel-building technique including thumbing, coiling or slab-building). In contrast, firing shows significantly more skill than do all other variables. There is also significantly more skill expressed in manufacturing than decoration, and more in handle symmetry than wall thickness, exterior surface treatment, decoration, rim deviation on the horizontal plane and profile symmetry. Firing, decoration or the application of handles need not be carried out by the same person that makes the body of the pot (Arnold 1985; Crown 2007). Thus while it is possible 
a

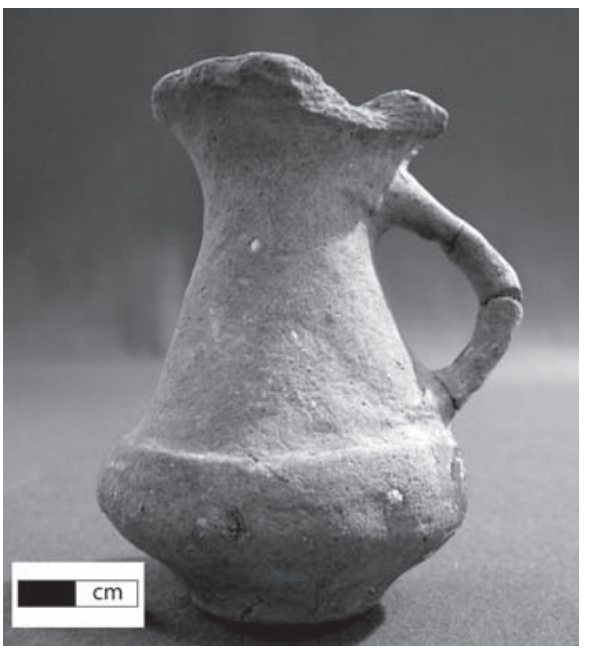

C

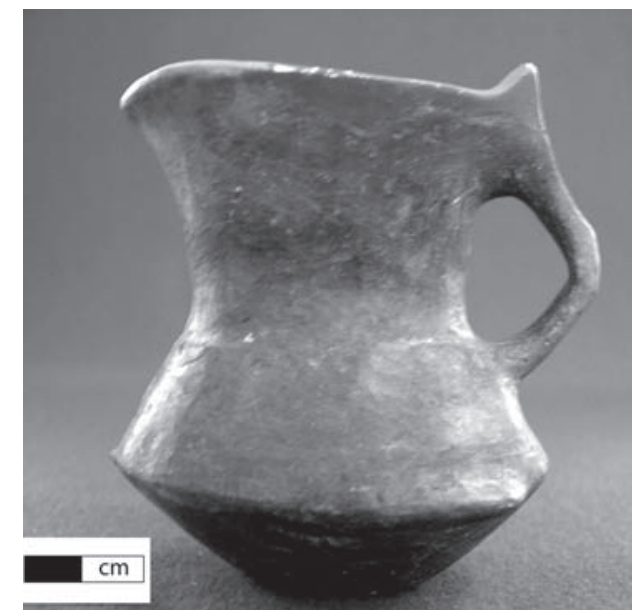

b

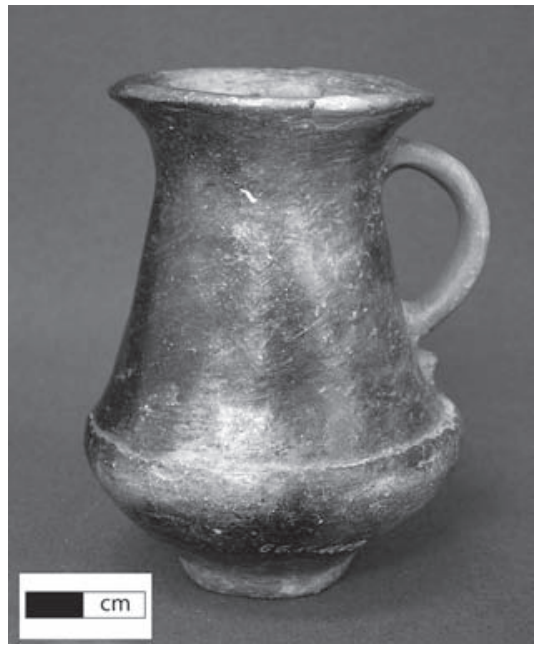

d

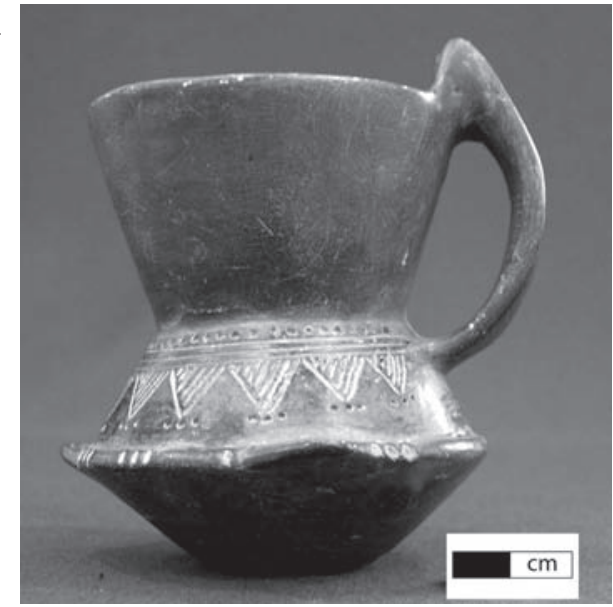

Figure 4. Skill variability at Százhalombatta: a) Nagyrév cup displaying poorly performed actions; b) Nagyrév cup displaying skilfully perfomed actions; c) Koszider cup displaying poorly performed actions; d) Koszider cup displaying skilfully performed actions.

to relate these results to differences in complexity of manufacture, some elements of pottery production being more complicated to master than others (the production of rims, for example, being particularly difficult), it is also possible to interpret them as the work of different individuals with contrasting skill levels. In other words, domestic vessels may be made by groups of people, with different parts worked on by potters with varying degrees of non-discursive knowledge, and thus different identities. Furthermore, this skill variability exists throughout the Százhalombatta assemblage across all periods of occupation activity for a range of vessel types (Budden 2007; Budden \& Sofaer in prep.), suggesting that differences in the expression of skill may be grounded in social institutions rather than chronological change.
Becoming a potter at Százhalombatta: non-discursive knowledge and the performance of potting

If potters and pots are physically created through the act of potting, then potters are socially created through the performance of potting. Recent important and inspirational archaeological engagements with performance have explored the construction of identity (e.g. Joyce 2000; 2006; Joyce \& Perry 2005; Shanks 2004; Wynne-Jones 2007), but these have tended to focus on the use and deployment of existing material culture, rather than performance in relation to the production of material culture. Furthermore, frequent (although not exclusive) use of the work of Judith Butler $(1993 ; 1990)$ to construct theoretical frameworks for performance, 


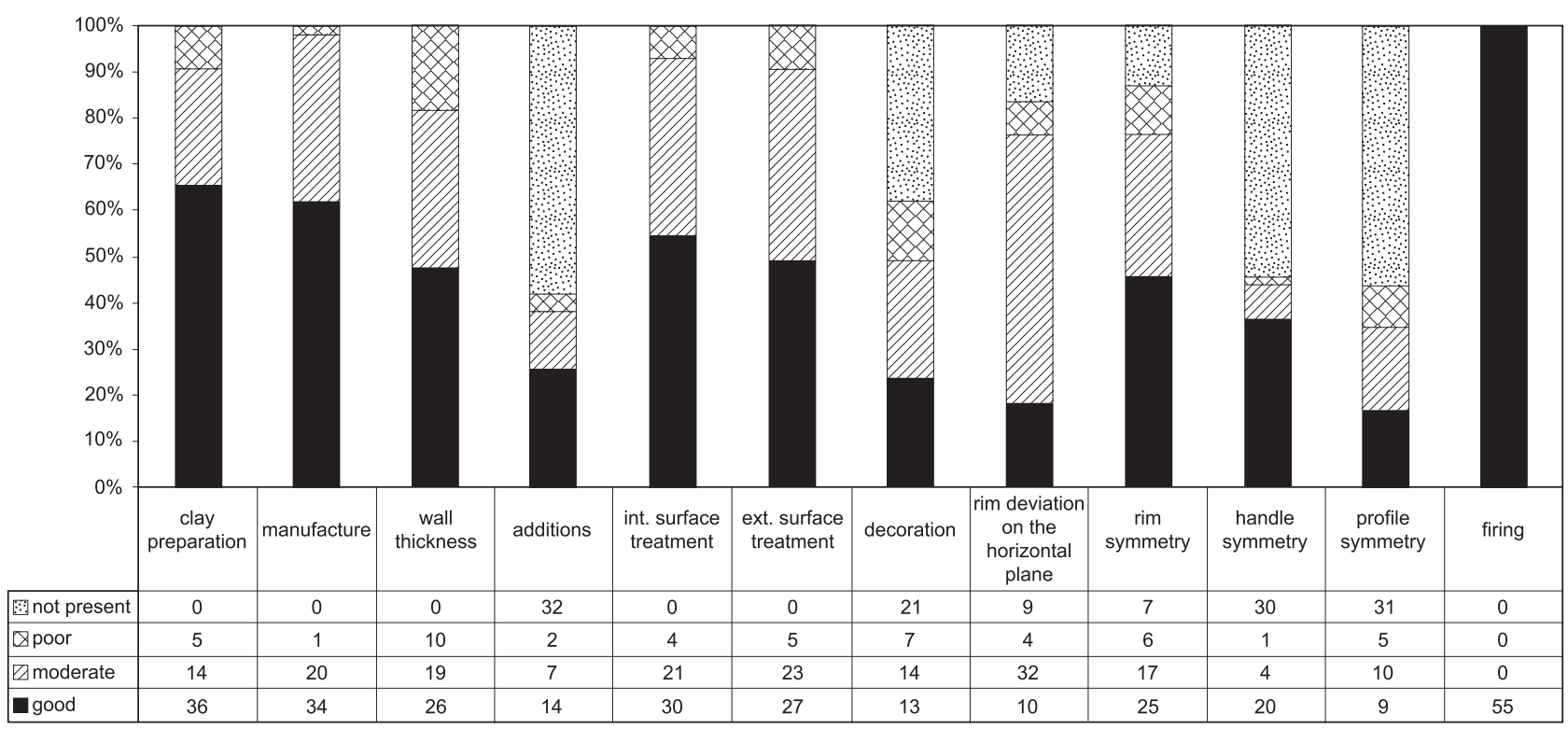

Figure 5. Skill variability in the production of domestic vessels at Százhalombatta for twelve technological variables.

Table 1. $\chi^{2}$ test for technological variables for Százhalombatta domestic vessels indicating skill variability between different aspects of vessel manufacture ( $\mathrm{df}=2$; sig. $\mathrm{p} \leq 0.05)$. All variables recorded as good, moderate or poor except firing which was categorized as soft, high or normal. (Entries in bold are significant results.)

\begin{tabular}{|c|c|c|c|c|c|c|c|c|c|c|c|c|}
\hline & \begin{tabular}{|l|} 
Clay \\
preparation
\end{tabular} & $\begin{array}{l}\text { Manu- } \\
\text { facture }\end{array}$ & \begin{tabular}{|l|}
$\begin{array}{l}\text { Wall } \\
\text { thickness }\end{array}$ \\
\end{tabular} & Additions & \begin{tabular}{|l|} 
Int. \\
surface \\
treatment
\end{tabular} & \begin{tabular}{|l|} 
Ext. \\
surface \\
treatment
\end{tabular} & Decoration & $\begin{array}{l}\text { Rim } \\
\text { deviation } \\
\text { on H. } \\
\text { plane }\end{array}$ & \begin{tabular}{|l|} 
Rim \\
symmetry
\end{tabular} & $\begin{array}{l}\text { Handle } \\
\text { symmetry }\end{array}$ & \begin{tabular}{|l|}
$\begin{array}{l}\text { Profile } \\
\text { symmetry }\end{array}$ \\
\end{tabular} & Firing \\
\hline \multicolumn{13}{|l|}{$\begin{array}{l}\text { Clay } \\
\text { preparation }\end{array}$} \\
\hline Manufacture & $\begin{array}{l}\chi^{2}=3.78 \\
p=0.15 \\
N=110\end{array}$ & & & & & & & & & & & \\
\hline $\begin{array}{l}\text { Wall } \\
\text { thickness }\end{array}$ & $\begin{array}{l}\chi^{2}=4.04 \\
p=0.13 \\
N=110\end{array}$ & $\begin{array}{l}\chi^{2}=8.46 \\
p=0.01 \\
N=110\end{array}$ & & & & & & & & & & \\
\hline Additions & $\begin{array}{l}\chi^{2}=0.21 \\
p=0.9 \\
N=78\end{array}$ & $\begin{array}{l}\chi^{2}=2.16 \\
p=0.34 \\
N=78\end{array}$ & $\begin{array}{l}\chi^{2}=1.62 \\
p=0.44 \\
N=78\end{array}$ & & & & & & & & & \\
\hline $\begin{array}{l}\text { Int. surface } \\
\text { treatment }\end{array}$ & $\begin{array}{l}\chi^{2}=2.06 \\
p=0.36 \\
N=110\end{array}$ & $\begin{array}{l}\chi^{2}=2.07 \\
p=0.36 \\
N=110\end{array}$ & $\begin{array}{l}\chi^{2}=2.96 \\
p=0.23 \\
N=110\end{array}$ & $\begin{array}{l}\chi^{2}=0.43 \\
p=0.81 \\
N=78\end{array}$ & & & & & & & & \\
\hline $\begin{array}{l}\text { Ext. surface } \\
\text { treatment }\end{array}$ & $\begin{array}{l}\chi^{2}=3.47 \\
p=0.18 \\
N=110\end{array}$ & $\begin{array}{l}\chi^{2}=3.68 \\
p=0.16 \\
N=110\end{array}$ & $\begin{array}{l}\chi^{2}=2.07 \\
p=0.36 \\
N=110\end{array}$ & $\begin{array}{l}\chi^{2}=0.98 \\
p=0.61 \\
N=78\end{array}$ & $\begin{array}{l}\chi^{2}=0.36 \\
p=0.84 \\
N=110\end{array}$ & & & & & & & \\
\hline Decoration & $\begin{array}{l}\chi^{2}=6.54 \\
p=0.04 \\
N=89\end{array}$ & $\begin{array}{l}\chi^{2}=10.58 \\
p=0.01 \\
N=89\end{array}$ & $\begin{array}{l}\chi^{2}=0.7 \\
p=0.70 \\
N=89\end{array}$ & $\begin{array}{l}\chi^{2}=3.14 \\
p=0.21 \\
N=78\end{array}$ & $\begin{array}{l}\chi^{2}=4.22 \\
p=0.12 \\
N=89\end{array}$ & $\begin{array}{l}\chi^{2}=2.61 \\
p=0.27 \\
N=89\end{array}$ & & & & & & \\
\hline $\begin{array}{l}\text { Rim } \\
\text { deviation on } \\
\text { H. plane }\end{array}$ & $\begin{array}{l}\chi^{2}=21.22 \\
p<0.0001 \\
N=101\end{array}$ & $\begin{array}{l}\chi^{2}=16.99 \\
p=0.0002 \\
N=101\end{array}$ & $\begin{array}{l}\chi^{2}=12.29 \\
p=0.002 \\
N=101\end{array}$ & $\begin{array}{l}\chi^{2}=10.9 \\
p=0.004 \\
N=78\end{array}$ & $\begin{array}{l}\chi^{2}=11.57 \\
p=0.003 \\
N=101\end{array}$ & $\begin{array}{l}\chi^{2}=8.66 \\
p=0.01 \\
N=101\end{array}$ & $\begin{array}{l}\chi^{2}=6.6 \\
p=0.04 \\
N=89\end{array}$ & & & & & \\
\hline $\begin{array}{l}\text { Rim } \\
\text { symmetry }\end{array}$ & $\begin{array}{l}\chi^{2}=1.9 \\
p=0.39 \\
N=103\end{array}$ & $\begin{array}{l}\chi^{2}=4.73 \\
p=0.09 \\
N=103\end{array}$ & $\begin{array}{l}\chi^{2}=0.66 \\
p=0.72 \\
N=103\end{array}$ & $\begin{array}{l}\chi^{2}=0.53 \\
p=0.77 \\
N=71\end{array}$ & $\begin{array}{l}\chi^{2}=0.8 \\
p=0.67 \\
N=103\end{array}$ & $\begin{array}{l}\chi^{2}=0.59 \\
p=0.74 \\
N=103\end{array}$ & $\begin{array}{l}\chi^{2}=1.82 \\
p=0.40 \\
N=82\end{array}$ & $\begin{array}{l}\chi^{2}=11.38 \\
p=0.003 \\
N=94\end{array}$ & & & & \\
\hline $\begin{array}{l}\text { Handle } \\
\text { symmetry }\end{array}$ & $\begin{array}{l}\chi^{2}=1.8 \\
p=0.41 \\
N=80\end{array}$ & $\begin{array}{l}\chi^{2}=3.54 \\
p=0.17 \\
N=80\end{array}$ & $\begin{array}{l}\chi^{2}=7.77 \\
p=0.02 \\
N=80\end{array}$ & $\begin{array}{l}\chi^{2}=2.13 \\
p=0.34 \\
N=43\end{array}$ & $\begin{array}{l}\chi^{2}=4.78 \\
p=0.09 \\
N=80\end{array}$ & \begin{tabular}{|l|}
$\chi^{2}=6.78$ \\
$p=0.03$ \\
$N=80$
\end{tabular} & $\begin{array}{l}\chi^{2}=10.41 \\
p=0.01 \\
N=59\end{array}$ & $\begin{array}{l}\chi^{2}=22.68 \\
p<0.0001 \\
N=71\end{array}$ & $\begin{array}{l}\chi^{2}=5.47 \\
p=0.06 \\
N=73\end{array}$ & & & \\
\hline $\begin{array}{l}\text { Profile } \\
\text { symmetry }\end{array}$ & $\begin{array}{l}\chi^{2}=5.56 \\
p=0.06 \\
N=79\end{array}$ & \begin{tabular}{|l|}
$\chi^{2}=9.89$ \\
$p=0.01$ \\
$N=79$
\end{tabular} & \begin{tabular}{|l|}
$\chi^{2}=0.65$ \\
$p=0.72$ \\
$N=79$
\end{tabular} & $\begin{array}{l}\chi^{2}=2.88 \\
p=0.24 \\
N=47\end{array}$ & \begin{tabular}{|l|}
$\chi^{2}=3.73$ \\
$p=0.15$ \\
$N=79$
\end{tabular} & $\begin{array}{l}\chi^{2}=2.31 \\
p=0.31 \\
N=79\end{array}$ & $\begin{array}{l}\chi^{2}=0.00 \\
p=1.00 \\
N=58\end{array}$ & $\begin{array}{l}\chi^{2}=5.3 \\
p=0.07 \\
N=70\end{array}$ & \begin{tabular}{|l|}
$\chi^{2}=1.61$ \\
$p=0.45$ \\
$N=72$
\end{tabular} & $\begin{array}{l}\chi^{2}=9.39 \\
p=0.009 \\
N=49\end{array}$ & & \\
\hline Firing & $\begin{array}{l}\chi^{2}=22.97 \\
p<0.0001 \\
N=110\end{array}$ & $\begin{array}{l}\chi^{2}=25.96 \\
p<0.0001 \\
N=110\end{array}$ & $\begin{array}{l}\chi^{2}=39.38 \\
p<0.0001 \\
N=110\end{array}$ & $\begin{array}{l}\chi^{2}=24.33 \\
p<0.0001 \\
N=78\end{array}$ & $\begin{array}{l}\chi^{2}=32.35 \\
p<0.0001 \\
N=110\end{array}$ & $\begin{array}{l}\chi^{2}=37.56 \\
p<0.0001 \\
N=110\end{array}$ & $\begin{array}{l}\chi^{2}=44.46 \\
p<0.0001 \\
N=89\end{array}$ & $\begin{array}{l}\chi^{2}=66.88 \\
p<0.0001 \\
N=101\end{array}$ & $\begin{array}{l}\chi^{2}=33.93 \\
p<0.0001 \\
N=103\end{array}$ & $\begin{array}{l}\chi^{2}=11.73 \\
p=0.002 \\
N=80\end{array}$ & $\begin{array}{l}\chi^{2}=42.43 \\
p<0.0001 \\
N=79\end{array}$ & \\
\hline
\end{tabular}


means that archaeologists have tended to highlight the role of discourse in the construction of self, placing less emphasis on both the non-discursive and the relationship between actor and audience.

An alternative exploration of performance comes from sociologist Erving Goffman and his work on faceto-face interactions. In The Presentation of Self in Everyday Life, Goffman (1959) uses the term 'performance' to refer to 'all the activity of an individual which occurs during a period marked by his continuous presence before a particular set of observers and which has some influence on the observers' and that 'renders the actor a particular kind of person in the eyes of the observers' (Goffman 1959, 32). Performances thus contribute to, and participate in, the construction of the worlds people inhabit. Similarly, approaches to performance theory in arts practice highlight that much of what people do in their everyday lives is a performance (Sofaer 2008). What is of interest here is not what a performance represents in a symbolic sense, but the nature of the performance itself - what it is, what it does and how it is done. Critically, non-discursive knowledge has to be in place in order to make a performance.

The audience also has a key role in the construction of public identity. To give an example of how this works it is possible to use the example of a novelist. A novelist can write a book in secret and publish it under a pseudonym. By doing this $\mathrm{s} / \mathrm{he}$ knows that $\mathrm{s} / \mathrm{he}$ is a novelist. But you do not. For you to identify him/her as a novelist you have to make a connection between the book and the author. In a non-literate society such as the Bronze Age and particularly in the case of the pottery at Százhalombatta where there is no evidence for potters' marks, performance must have been a key means of making connections; audiences would have to see actors performing in order to know that they hold particular identities. Observers would then be able to pass on knowledge orally about an individual's actions, thereby creating discursive knowledge about that person's identity. In this sense, the non-discursive precedes the discursive in identity formation.

Using the analogy of the stage, Goffman highlights the role of the material world in performance through an emphasis on the role of props and settings in performative acts. Thus an actor performs in a setting which is constructed of a stage and a backstage. The props at either setting direct his action; he is being watched by an audience, but at the same time he is an audience for his viewers' play. According to Goffman, the social actor has the ability to choose his stage and props, as well as the costume he would put on in front of a specific audience. The actor's main goal is to keep his coherence, and adjust to the different settings offered him. This is done mainly through interaction with other actors, including the audience (Goffman 1959). To a certain extent, this imagery bridges structure and agency, enabling and constraining each participant (Hacking 2004).

To illustrate, Goffman $(1959,81)$ famously cites Sartre's (1957) example of the waiter in the café:

\footnotetext{
His movement is quick and forward, a little too precise, a little too rapid. He comes towards the patrons with a step a little too quick. He bends forward a little too eagerly; his voice, his eyes express an interest a little too solicitous for the order of the customer....He applies himself to chaining his movements as if they were mechanisms, the one regulating the other; his gestures and even his voice seem to be mechanisms; he gives himself the quickness and pitiless rapidity of things. He is playing, he is amusing himself. But what is he playing? We need not watch for long before we can explain it: he playing at being a waiter in a café. ...The child plays with his body in order to explore it, to take inventory of it; the waiter in the café plays with his condition in order to realize it. This obligation is not different from that which is imposed on all tradesmen. Their condition is wholly one of ceremony. The public demands of them that they realize it as ceremony; there is the dance of the grocer, of the tailor, of the auctioneer, by which they endeavour to persuade their clientele that they are nothing but a grocer, an auctioneer, a tailor. A grocer who dreams is offensive to the buyer, because such a grocer is not wholly a grocer. Society demands that he limit himself to his function as a grocer, just as the soldier at attention makes himself into a soldier-thing with a direct regard which does not see at all...
}

The emphasis on the coherence of identity expressed by Goffman also distinguishes his work from that of Butler (1993; 1990) and others who have stressed the fractured and multiple nature of human identities (e.g. Meskell 1999; Moore 1994). While both the principle and the understanding of the fluidity of human identity are important, Goffman's work is useful for exploring what messages people want to convey in a given context, rather than the analysis of the range of identities they may potentially express. Indeed, the need to aim for coherence in performance is precisely because it is all too easy to slip into other roles. Furthermore, people in strongly hierarchical rule-bound societies, such as existed in the European Bronze Age, may have been more constrained with regard to their identities and freedom of performance than the postmodern condition permits. Their need for coherence may therefore have been particularly strong. 
Potters and the construction of identity

For Bronze Age potters, the construction of their identity as potters took place through the performance of non-discursive knowledge associated with potting. Potters were the actors, while the clay, tools, fire and pots in preparation became props and settings. Studies of pottery production strongly indicate the social nature of pottery production with potters working with people around them rather than in isolation (Arnold 1985; Barley 1994; David 1990; Gosselain 1992; 2001). Potting therefore took place in front of an audience. While a potter's workshop has not yet been found at Százhalombatta, there are numerous examples of potential kilns and some wasters, as well as unfired clay objects. Furthermore, the nature of pottery production in the Bronze Age with open firings, sometimes of very large vessels, and the necessity to produce pottery at certain time of year as an outdoors activity (for example sun-baking of pots to dry them), must have meant a public engagement with, and awareness of, pottery production even where specialist potters were involved. Thus while not all members of a community may have spent their days observing potters and pottery making, there were enough people who had seen a given potter in action for discursive knowledge about his or her identity as a potter to circulate.

However, the need to perform in order to have identity recognized makes the actor vulnerable. A performance cannot be just any performance which an actor chooses to make but must be socially sanctioned. The example of potters from the neighbourhood of
San Juan Batista in the city of San Nicolas, northwest Philippines (Longacre et al. 2000) demonstrates this well. These potters produce cooking pots with a shiny black surface that are readily identifiable by consumers from the red vessels made by potters from other neighbourhoods. Consumers, in turn, identify these pots as better-made and more durable than pots made elsewhere, a perception borne out by experimental work (Longacre et al. 2000). The pots are not sold directly to consumers but through wholesalers who act as middlemen. The wholesaler will not buy red pots from San Juan Batista, nor will the potters from there alter their production processes because they believe that their product will not be as good, even if they could increase their profit margin by doing so. In other words, San Juan Batista potters are reluctant to change their way of working because it would mean that they had not performed correctly. Erroneous performances therefore threaten to destabilize the identity of potter. Only apprentice potters who have not yet acquired the full identity of potter - because they have not yet acquired the full range of non-discursive knowledge and concomitant proficiency in techniques - can 'afford' to make 'bad' pots, although for even the most experienced potter things may sometimes go wrong.

To illustrate this archaeologically it is possible to compare two different vessel types from Százhalombatta which are on opposite ends of a scale of manufacturing complexity: cups and fineware (Table 2). Not all pots require the same investment of skill in order to produce a successful outcome (Arnold 1985;

Table 2. Degrees of technical complexity for vessel forms at Százhalombatta.

\begin{tabular}{|l|l|l|}
\hline Vessel type & Characteristics & Degree of technical complexity \\
\hline Cups & $\begin{array}{l}\text { Small, ubiquitous vessels the majority of which have } \\
\text { simple morphologies }\end{array}$ & Easiest \\
\hline Domestic vessels & $\begin{array}{l}\text { Generally of moderate size with comparatively } \\
\text { neutral shapes }\end{array}$ & Intermediate \\
\hline Urns & $\begin{array}{l}\text { Often very large with complex morphologies, } \\
\text { additions and embellishments }\end{array}$ & $\begin{array}{l}\text { Complex tripartite forms with highly exagerrated } \\
\text { morphology, complex handles and embellishments, } \\
\text { and very fine wall thickness }\end{array}$ \\
\hline Fineware & Very technically demanding demanding \\
\hline
\end{tabular}


Caiger-Smith 1995; Rhodes 1957; Rice 1987; Rye 1981). Among the many criteria governing the required investment of skill in relation to a successful outcome are vessel size and morphological characteristics. Smaller, simpler forms require lower degrees of skill to produce than large complex ones. Given that cups are the least technically demanding form made at Százhalombatta one might expect that, if they were all made by experienced potters, they should show the least amount of error. Fineware, being more complicated to make, should demonstrate more errors. What we find, however, is the reverse (Table 3). In other words, cups are much more error-prone with a significantly lower investment of skill. The only exception to this is firing.

We can interpret this pattern as a reflection of differences in performance and social identity. In order to be able to make fineware, potters have to go through the process of learning to make less complex vessels such as cups (cf. Singleton 1998b). Cups may therefore represent the work of apprentice or learner potters. The fact that finewares show relatively little error overall reflects the control over performance and the material articulation of accumulated nondiscursive knowledge of experienced professional potters, while the accurate firing of both vessel types suggests the existence of skilled practitioners who took on the firing of a range of different vessels. The data from Százhalombatta therefore reflect the difference between being acknowledged as a skilled performer with a solid identity, and an unskilled performer with a weaker more unstable one. ${ }^{3}$ At
Százhalombatta, the construction of potters' identities - or to use Hacking's (2004) phrase the 'making up' of potters - is therefore the result of the relationship between the body actions of the potter as performer and the non-discursive knowledge of the audience. There may be many different forms and strengths of identity through the contrasting performances that people may give. Thus apprentice potters have the potential to become recognized as full potters through the repeated successful enactment of non-discursive knowledge. The corollary to this is that, once identity is fully accredited through repeated competent performance, the performance needs to be maintained for identity to be maintained.

What happens then if performances are not maintained? At Százhalombatta, in a final narrow stratigraphic horizon of the Middle Bronze Age Koszider phase representing the emerging transition to the Late Bronze Age, the investment of skill in pottery declines, particularly for urns, domestic vessels and fine wares. ${ }^{4}$ While ceramic forms and manufacturing techniques remain the same, vessel walls become thicker and the quality of fabrics declines, particularly for storage vessels and urns where previously tight, fine fabrics are replaced by chunkier, looser, coarser tempered vessels where the clay has not been as wellprepared (Sofaer \& Vicze in prep.). This suggests an attempt to maintain previous vessel forms without fully skilled implementation of other technical aspects of the potting process.

A consideration of performance, technique and identity allows us to suggest an interpretation for

Table 3. $\chi^{2}$ test for technological variables recorded for cups and fineware at Százhalombatta indicating variability in skill investment between the vessel types ( $\mathrm{df}=2 ;$ sig. $\mathrm{p} \leq 0.05)$. The results reflect a low investment of skill for cups and a high investment of skill for fineware for all variables except firing.

\begin{tabular}{|l|c|c|c|c|c|c|c|c|}
\cline { 2 - 9 } \multicolumn{1}{c|}{} & \multicolumn{3}{c|}{ Cups } & \multicolumn{3}{c|}{ Fineware } & \multicolumn{2}{c|}{$\chi^{2}$ Cups/Fineware } \\
\hline Technological variable & Good & Moderate & Poor & Good & Moderate & Poor & $\chi^{2}$ & $p \leq 0.05$ \\
\hline Clay preparation & $67(48.0 \%)$ & $47(34.0 \%)$ & $27(18.0 \%)$ & $82(85.0 \%)$ & $12(12.0 \%)$ & $3(3.0 \%)$ & 36.773 & 0.000 \\
\hline Manufacturing & $52(37.0 \%)$ & $49(35.0 \%)$ & $39(28.0 \%)$ & $66(68.0 \%)$ & $28(29.0 \%)$ & $3(3.0 \%)$ & 36.230 & 0.000 \\
\hline Wall thickness & $58(43.0 \%)$ & $34(25.0 \%)$ & $43(32.0 \%)$ & $63(66.3 \%)$ & $25(26.3 \%)$ & $7(7.3 \%)$ & 23.411 & 0.000 \\
\hline Additions & $34(38.0 \%)$ & $25(27.0 \%)$ & $32(35.0 \%)$ & $42(69.0 \%)$ & $14(23.0 \%)$ & $5(8.0 \%)$ & 20.015 & 0.000 \\
\hline Interior surface treatment & $57(45.0 \%)$ & $33(26.0 \%)$ & $37(29.0 \%)$ & $73(75.0 \%)$ & $17(18.0 \%)$ & $7(7.0 \%)$ & 25.594 & 0.000 \\
\hline Exterior surface treatment & $55(40.0 \%)$ & $48(35.0 \%)$ & $34(25.0 \%)$ & $79(82.0 \%)$ & $11(11.5 \%)$ & $6(6.5 \%)$ & 43.735 & 0.000 \\
\hline Decoration & $14(59.0 \%)$ & $1(4.0 \%)$ & $9(37.0 \%)$ & $44(70.0 \%)$ & $15(24.0 \%)$ & $4(6.0 \%)$ & 15.278 & $0.000^{*}$ \\
\hline Rim deviation on H. plane & $14(16.0 \%)$ & $49(54.0 \%)$ & $27(30.0 \%)$ & $35(50.0 \%)$ & $28(40.0 \%)$ & $7(10.0 \%)$ & 25.151 & 0.000 \\
\hline Rim symmetry & $43(51.0 \%)$ & $36(43.0 \%)$ & $5(6.0 \%)$ & $59(74.0 \%)$ & $16(20.0 \%)$ & $5(6.0 \%)$ & 10.111 & $0.006^{*}$ \\
\hline Handle symmetry & $46(51.5 \%)$ & $30(34.0 \%)$ & $13(14.5 \%)$ & $47(81.0 \%)$ & $7(12.0 \%)$ & $4(7.0 \%)$ & 13.840 & 0.001 \\
\hline Profile symmetry & $45(39.0 \%)$ & $43(38.0 \%)$ & $27(23.0 \%)$ & $45(78.0 \%)$ & $9(15.0 \%)$ & $4(7.0 \%)$ & 24.169 & 0.000 \\
\hline Firing & Soft & High & Normal & Soft & High & Normal & $\chi^{2}$ & $p \leq 0.05$ \\
\hline
\end{tabular}

Cups $N=140 /$ Fineware $N=97$. Note: * indicates Pearson value. 
this apparent break-down in skill based on shifts in knowledge bases and identities. At Százhalombatta, the creation and maintenance of potters as a social category was essential to the ongoing creation of specific forms of material culture. At the very end of the Middle Bronze Age, however, an attempt to maintain vessel shapes without proper articulation of all previous stages in the manufacturing process meant that the performances of potters lost their coherence as the articulation of non-discursive knowledge through techniques of the body was not maintained. As a result, material culture changed. This would have led not only to alteration of ceramic traditions, but to shifts in social views of potters as their social identities changed over time through new, altered or failed performances. In turn, this would have resulted in the establishment of new social dynamics.

To understand the circumstances under which such change in performance might take place it is useful to turn to the ethnographic record. In his study of craftspeople on the island of Crete, Michael Herzfeld reveals a hegemonic system where masters have almost unlimited power over their apprentices (Herzfeld 2004). Master craftspeople are reluctant to show their apprentices all the skills of their trade, partly because it is expensive in time and materials, but also because passing on all their knowledge would create new masters who would then constitute a threat to existing ones. Apprentices in their turn resort to all kinds of devious methods to uncover their master's secrets (Herzfeld 2004). Similarly, in Japan potters' apprentices are forced to 'steal' their master's secrets if they wish to progress (Singleton 1989). Crown (1999, 26) notes that ability to pot is related to the social and physical environment, ideas of socialization, access to visual stimuli, access to materials and the social status of art within society. Since finewares at Százhalombatta were prestige objects used in display (Sofaer 2006b), knowledge regarding how to make them would be highly valuable and worth protecting. If 'knowledge is power', then it may be that at the end of the Middle Bronze Age existing power structures surrounding the control of potting knowledge become almost too effective. Apprentices were therefore unable to acquire non-discursive knowledge because the access to knowledge channels was cut off. New potters were therefore unable to maintain socially sanctioned performances, resulting in change in ceramics. The impact of such a removal of access to knowledge would be particularly swift in a society with a strongly hierarchical learning system where the acquisition of knowledge took place under supervised conditions.
This over-protection of knowledge may also imply a shift in social structure. In a previous article on pots, houses and metal at Százhalombatta, Sofaer (2006b) suggests that there was an exchange of knowledge between crafts, in particular pottery, metalwork and house building, on the basis of technical relationships between objects. In a highly stratified hierarchical society strongly concerned with prestige such as existed in the European Bronze Age (Earle 2002; Harding 2007; Kristiansen 1998; 2000), the transfer of knowledge may have been linked to the existence of a caste-like system, since such systems form a network in which the exchange of knowledge can take place between craftspeople (Sofaer 2006b). Caste-like systems are endogamous, with restrictions on commensality between members of different castes. However, they may also be more flexible than is often suggested, with groups rising or falling within its rankings (Coningham \& Young 1999, 92), thereby allowing for the possibility of social change. If the circulation of knowledge is more effective in structures based round kin groups where masters have a vested interest in the transfer of information that secures their own group, then a concern with the protection of knowledge may indicate internal power struggles and a change in family networks. It may suggest that the internal social structures of the community of craftspeople were more complex than we have hitherto considered, and that perhaps these led to the eventual reconfiguration of that system at the end of the Middle Bronze Age.

\section{Conclusion}

In this article we have sought to explore the role of non-discursive knowledge in the construction of identity by examining the relationship between the making of things and the making of people. Potters at Százhalombatta were created in two distinct but complementary ways. First, potters literally came into being as potters through those techniques of the body learnt through repeated bodily enactment of potting skills and their engagement with materials and tools. This is a case of the acquisition of non-discursive knowledge by the potter him/herself. Second, potters gained their identity as potters in the social sphere through the inter-subjective connection between the potter's performance and his or her audience. Here, the non-discursive knowledge of the potter must be matched to the discursive knowledge of his or her audience who recognize a potter as a potter through his/her performance.

Beyond the identification of skill levels associated with a range of potter's identities from starter 
apprentice to master we have not aimed to look at who made the pots. Whether potters at Százhalombatta were men or women, or whether both were involved in pottery production remains an open question. Rather, we have aimed to examine the role of nondiscursive knowledge in the construction of a more fluid notion of identity. Such an investigation of the construction of identity in relation to actions involved in the production of material culture has potential to provide a quite different view of social dynamics to material culture viewed as 'finished object'. Instead of viewing people through their associations with objects in a coarse grained way as in traditional methods of artefact association, we have tried to gain a more nuanced picture of Bronze Age society. Tracing non-discursive knowledge at Százhalombatta by identifying different levels of potting skill allows us to consider the expression of many different forms and strengths of identity even within the single social category of potter; qualitatively different performances that people gave in the production of pots are materially expressed. The articulation of knowledge also lies at the heart of cultural change. At the very end of the Middle Bronze Age, changes in access to knowledge led to shifts in performance, and thus to altered forms of identity and material expression.

\section{Acknowledgements}

An early version of this article was first presented at the 12th Annual EAA meeting in Krakow, 2006 in the session Knowledge, Belief and the Body organized by Marie-Louise Stig Sørensen, Katharina Rebay and Jessica Hughes. We would like to thank them for inviting us to participate and for their valuable feedback. We are also grateful to Patricia Crown and William Parkinson for their thoughtful comments. Magdolna Vicze gave us invaluable support. Finally, thanks are due to baby Gad Sofaer for time taken out of maternity leave to think about pots and potters.

\section{Notes}

1. The SAX Project also forms part of the wider ECfunded projects the Emergence of European Communities (2002-2006) and Forging Identities: the Mobility of Culture in Europe (2009-2012).

2. A fuller account of these scoring criteria and associated skills methodology is given by Budden (2007; 2008).

3. Again, it is important to note here that it is impossible to unlearn skill because non-discursive knowledge becomes literally embodied in the person through physical changes to their neurology, musculature or skeleton. 'Poorly made' pots are not necessarily just pots made in a hurry (cf. Crown 1999; 2001)!

4. Data from this horizon are not included in tables and figures presented earlier in this article.

\author{
Sandy Budden \\ Department of Archaeology \\ Avenue Campus \\ Highfield \\ Southampton \\ SO17 1BF \\ $U K$ \\ Email: S.A.Budden@soton.ac.uk \\ Joanna Sofaer \\ Department of Archaeology \\ Avenue Campus \\ Highfield \\ Southampton \\ SO17 1BF \\ $U K$ \\ Email:jrsd@soton.ac.uk
}

\section{References}

Anderson, J.R., 1982. Acquisition of cognitive skill. Psychological Review 89(4), 369-406.

Anderson, J.R., 1983. The Architecture of Cognition. Cambridge (MA): Harvard University Press.

Anderson, J.R., 1987. Skill acquisition compilation of weakmethod problem solutions. Psychological Review 94(2), 192-210.

Arnold, D., 1985. Ceramic Theory and Cultural Process. Cambridge: Cambridge University Press.

Barley, N., 1994. Smashing Pots Feats of Clay from Africa. London: British Museum Press.

Bóna, I., 1975. Die Mittlere Bronzezeit Ungarns und ihre sudostlichen Bezielumgen. Budapest: Akadémia Kiadó.

Bóna, I., 1992. Bronzezeit Tell-Kulturen in Ungarn, in Bronzezeit in Ungarn. Forschungen in Tell-Siedlungen an Donau und Theiss, ed. I. Bóna. Frankfurt am Main, 9-13.

Braun, D., 1983. Pots as tools, in Archaeological Hammers and Theories, eds. J.A. Moore \& A.S. Keene. New York (NY): Academic Press, 107-34.

Budden, S., 2007. Renewal and Reinvention: the Role of Learning Strategies in the Early to Late Bronze Age of the Carpathian Basin. Unpublished PhD, University of Southampton.

Budden, S., 2008. Skill amongst the sherds: understanding the role of skill in the Early to Late Middle Bronze Age in Hungary, in Breaking the Mould: Challenging the Past through Pottery, Manchester 2006, ed. I. Berg. (British Archaeological Reports International Series 1861.) Oxford: BAR, 1-17.

Budden, S. \& J. Sofaer, in prep. Making pots and making people: skill and embodied knowledge at the Bronze Age tell at Százhalombatta, Hungary, in Embodied Knowledge, eds. M.L.S. Sørensen \& K. Rebay. Oxford: Oxbow.

Butler, J., 1990. Gender Trouble: Feminism and the Subversion of Identity. New York (NY): Routledge. 
Butler, J., 1993. Bodies That Matter. New York (NY): Routledge. Butler, J.J., 1966. Bell Beakers and early metallurgy in the Netherlands. Palaeohistoria 12, 41-139.

Caiger-Smith, A., 1995. Pottery, People and Time. Somerset: Richard Dennis.

Chalkin, S. \& J. Lave (eds.), 1996. Understanding Practice. Perspectives on Activity and Context. Cambridge: Cambridge University Press.

Coningham, R. \& R. Young, 1999. The archaeological visibility of caste: an introduction, in Case Studies in Archaeology and World Religion. The Proceedings of the Cambridge Conference, ed. T. Insoll. (British Archaeological Reports International Series 755.) Oxford: Archaeopress, 84-93.

Crown, P.L., 1999. Socialisation in American Southwest pottery decoration, in Pottery and People, eds. J.M. Skibo \& G.M. Feinman. Salt Lake City (UT): University of Utah, 25-43.

Crown, P.L., 2001. Learning to make pottery in the Prehispanic American Southwest. Journal of Anthropological Research 57, 451-69.

Crown, P.L., 2007. Life histories of pots and potters: situating the individual in archaeology. American Antiquity 72(4), 677-90.

David, N., 1990. Vessels of the Spirit: Pots and People in North Cameroon. (Video.) Calgary: University of Calgary.

Dickens, P., 2001. Linking the social and natural sciences: is capital modifying biology in its own image? Sociology 35(1), 93-110.

Dobres, M.A., 1999. Technology's links and chaines: the processual unfolding of technique and technician, in The Social Dynamics of Technology: Practice, Politics and World Views, eds. M.A. Dobres \& C.R. Hoffman. London: Smithsonian Institute, 124-46.

Dobres, M.A., 2000. Technology and Social Agency. Oxford: Blackwell.

Dobres, M.A. \& C.R. Hoffman, 1994. Social agency and the dynamics of prehistoric technology. Journal of Archaeological Method and Theory 1(3), 211-58.

Earle, T., 2002. Bronze Age Economics: the Beginnings of Political Economies. Oxford: Westview Press.

Edmonds, M., 1990. Description, understanding and the chaîne opératoire. Archaeological Review from Cambridge 9, 55-70.

Foucault, M., 1969 [2002]. The Archaeology of Knowledge. London: Routledge.

Gamble, C., 2007. Origins and Revolutions: Human Identity in Earliest Prehistory. Cambridge University Press: Cambridge.

Gardner, H., 1993. Frames of Mind: the Theory of Multiple Intelligences. 2nd edition. London: Fontana Press.

Gardner, H., 1999. Intelligence Reframed: Multiple Intelligences for the 21st Century. New York (NY): Basic Books.

Gelbert, A., 1999. Technological and stylistic borrowings between ceramic traditions: a case study from northeastern Senegal, in Ethno-analogy and Reconstruction of Prehistoric Artefact Use and Production, eds. L.R. Owen \& M. Porr. (Urgeschichtliche Materialhefte 14.) Tübingen: Mo Vince Verlag, 201-24.
Goffman, E., 1959 [1990]. The Presentation of Self in Everyday Life. London: Penguin.

Goffman, E., 1967. Interaction Ritual: Essays on Face to Face Behaviour. New York (NY): Doubleday.

Gosselain, O.P., 1992. Technology and style: potters and pottery among the Bafia of Cameroon. Man 27, 559-86.

Gosselain, O.P., 1999. In pots we trust: the processing of clay and symbols in Sub-Sahran Africa. Journal of Material Culture 4(2), 205-30.

Gosselain O.P., 2000. Materializing identities: an African perspective. Journal of Archaeological Method and Theory 7, 187-217.

Gosselain, O.P., 2001. Globalizing local pottery studies, in Ethnoarchaeology and its Transfers, eds. S. Beyries \& P. Pétrequin. (British Archaeological Reports International Series 983.) Oxford: BAR, 95-111.

Hacking, I., 2004. Between Michel Foucault and Erving Goffman: between discourse in the abstract and face-toface interaction. Economy and Society 33(3), 277-302.

Harding, A., 2007. Warriors and Weapons in Bronze Age Europe. Budapest: Archaeolingua.

Herzfeld, M., 2004. The Body Impolitic: Artisans and Artifice in the Global Hierarchy of Value. Chicago (IL): The University of Chicago Press.

Hodder, I., 1982. Symbols in Action. Cambridge: Cambridge University Press.

Hodder, I., 1991. The decoration of containers: an ethnographic and historical study, in Ceramic Ethnoarchaeology, ed. W. Longacre. Tucson (AZ): University of Arizona Press.

Hodder, I., 1992. Theory and Practice in Archaeology. London: Routledge.

Hodder, I., 1993. Social cognition, in 'Viewpoint: What is Cognitive Archaeology', by C. Renfrew, C. Peebles, I. Hodder, B. Bender, K. Flannery \& J. Marcus. Cambridge Archaeological Journal 3(2), 247-70.

Ingold, T., 1990. Society, nature and the concept of technology. Archaeological Review from Cambridge 9(1), 5-17.

Ingold, T., 1993. Technology, language, intelligence: a reconsideration of basic concepts, in Tools, Language and Cognition in Human Evolution, eds. K.R. Gibson \& T. Ingold. Cambridge: Cambridge University Press, 449-72.

Ingold, T., 1998. From complimentary to obviation: on dissolving the boundaries between social and biological anthropology, archaeology and psychology. Zeitschrift für Ethnologie 123, 21-52.

Ingold, T., 1999. Foreword, in The Social Dynamics of Technology, eds. M.A. Dobres \& C.R. Hoffman. London: Smithsonian Institute.

Ingold, T., 2000. The Perception of the Environment: Essays on Livelihood, Dwelling and Skill. London: Routledge.

Ingold, T., 2001. Beyond art and technology: the anthropology of skill, in Anthropological Perspectives on Technology, ed. M.B. Schiffer. Albuquerque (NM): University of New Mexico Press, 17-31.

Ingold, T., 2007. Materials against materiality. Archaeological Dialogues 14(1), 1-15.

Joyce, R., 2000. Girling the girl and boying the boy: the 
production of adulthood in ancient Mesoamerica. World Archaeology 31, 473-83.

Joyce, R. 2006. Feminist theories of embodiment and the anthropological imagination: making bodies matter, in Feminist Anthropology Past, Present and Future, eds. P. Geller \& M. Stocking. Philadelphia (PA): University of Pennsylvania Press, 43-54.

Joyce, R. \& E. Perry, 2005. Past performance: the archaeology of gender as influenced by the work of Judith Butler, in Butler Matters: Judith Butler's Impact on Feminist and Queer Studies, eds. M. Sönser Breen \& W. Blumenfeld. Aldershot: Ashgate, 113-26.

Kamp, K.A., 2001. Prehistoric children working and playing: a southwestern case study in learning ceramics. Journal of Anthropological Research 57, 427-50.

Keating, D. \& F. Miller, 1999. Individual pathways in competence and coping: from regulatory systems to habits of mind, in Developmental Health and the Wealth of Nations, eds. D. Keating \& C. Hertzman. New York (NY): Guildford, 220-34.

Knappett, C., 2005. Thinking through Material Culture: an Interdisciplinary Perspective. Philadelphia (PA): University of Pennsylvania Press.

Kramer, C., 1985. Ceramic ethnoarchaeology. Annual Review of Anthropology 14, 77-102.

Kovács, T., 1969. A százhalombattai bronzkori telep. [The Bronze Age settlement at Százhalombatta.] Archaeologiai Értesítő 96, 161-9.

Kreiter, A., B. Bajnóczi, P. Sipos, G. Szakmány \& M. Tóth, 2007. Archaeometric examination of Early and Middle Bronze Age ceramics from Százhalombatta-Földvár, Hungary. Archeometriai Múhely 2, 33-46.

Kristiansen, K., 1998. Europe before History. Cambridge: Cambridge University Press.

Kristiansen, K., 2000. Emergence of European communities: household, settlement and territory in Later Prehistory (2300-300 вс), in Százhalombatta Archaeological Expedition SAX Annual Report 1, eds. I. Poroszlai \& M. Vicse. Hungary: Matrica Museum, 7-11.

Latour, B., 2005. Reassembling the Social: an Introduction to Actor Network Theory. Oxford: Oxford University Press.

van der Leeuw, S. E., D.A. Papousek \& A. Coudart, 1991. Technical traditions and unquestioned assumptions: the case of pottery in Michoacan. Techniques et Culture $17-18,145-73$.

Lemonnier, P., 1990. Topsy turvy techniques remarks on the social representation of techniques. Archaeological Review from Cambridge 9(1), 27-37.

Lemonnier, P., 1992a. Elements for an Anthropology of Technology. (Museum of Anthropology, University of Michigan Anthropological Papers 88.) Ann Arbor (MI): University of Michigan.

Lemonnier, P., 1992b. Leroi-Gourhan: ethnologue des techniques. Les Nouvelles de l'Archaeologie 48-9, 13-17.

Leroi-Gourhan, A., 1943. Evolution et techniques: l'homme et le Matiére. Paris: Albin Michel.

Leroi-Gourhan, A., 1945. Evolution et techniques: milieu et techniques. Paris: Albin Michel.
Longacre, W.A., J. Xia \& Y. Tao, 2000. I want to buy a black pot. Journal of Archaeological Method and Theory 7(4), 273-93.

Mauss, M., 1927. Divisions et proportion des divisions de la sociologie. [The divisions of sociology.] Année sociologique (second series) 2, 98-176.

Mauss, M., 1935 [2006]. Les techniques du corps, in Marcel Mauss: Techniques, Technology and Civilisation, ed. N. Schlanger, trans. B. Brewster. Oxford: Durkheim Press, 77-95. [Previously published in Economy and Society 1973.]

Mauss, M., 1947. Technology manuel d'ethnographie, in Marcel Mauss: Techniques, Technology and Civilisation, ed. N. Schlanger, trans. D. Lussier. Oxford: Durkheim Press, 97-140. [Previously published in Paris: Paypout second edition 1967.]

Meskell, L., 1999. Archaeologies of Social Life: Age, Sex, Class et cetera in Ancient Egypt. Oxford: Blackwell.

Moore, H., 1994. A Passion for Difference: Essays in Anthropology and Gender. Cambridge: Polity Press.

Pffafenberger, B., 1992. Social Anthropology of technology. Annual Review of Anthropology 21, 491-516.

Pfaffenberger, B., 1999. Worlds in the making: technological activities and the construction of intersubjective meaning, in The Social Dynamics of Technology, eds. M.A. Dobres \& C.R. Hoffman. London: Smithsonian Institution, 147-64.

Pigeot, N., 1990. Technical and social actors: flintknapping specialists at Magdelanian Etilles. Archaeological Review from Cambridge 9(1), 126-41.

Pigeot, N., 1991. Réfelexions sur l'histoire technique de l'homme: de l'homme cognitive á l'evolution culturelle. Paléo: Revue d'Archéologie Préhistorique 3, $167-200$.

Poroszlai, I., 1996. Excavations at Százhalombatta 1989-1995. Százhalombatta: Matrica Museum.

Poroszlai, I., 2000. Excavation campaigns at the Bronze Age site at Százhalambatta-Földvár, in Százhalombatta Archaeological Expedition SAX Annual Report 1, eds. I. Poroszlai \& M. Vicze. Százhalombatta: Archaeolingua, 13-73.

Poroszlai, I. 2003. Fortified centres along the Danube, in Hungarian Archaeology at the Turn of the Millennium, ed. Z. Visy. Budapest: Ministry of National Cultural Heritage, 151-5.

Rice, P.M., 1987. Pottery Analysis: a Sourcebook. Chicago (IL): The University of Chicago Press.

Rhodes, D., 1957. Clay and Glazes for the Potter. Philadelphia (PA): Chilton Book Company.

Rogoff, B., 1990. Apprenticeship in Thinking: Cognitive Development in Social Context. Oxford: Oxford University Press.

Roux, V., 1990. The psychological analysis of technical activities: a contribution to the study of craft specialisation. Archaeological Review from Cambridge 9(1), 142-51.

Roux, V. \& P. Blasco, 2000. Cornaline de l'Inde/Carnelian in India. From Technical Practices in Cambay to the Technosystems of the Indus. Paris: Editions de la Maison des Sciences de L'Homme. 
Rye, O., 1981. Pottery Technology: Principles and Reconstruction. Washington (DC): Taraxum.

Sartre, J.-P., 1957. Being and Nothingness: an Essay on Phenomenological Ontology, trans. H. Barnes. London: Methuen.

Schlanger, N., 2006. Marcel Mauss: Techniques, Technology and Civilisation. Oxford: Durkheim Press.

Shanks, M., 2004. Three rooms: archaeology and performance. Journal of Social Archaeology 4(2), 147-80.

Shell, C., 2000. Metalworker or shaman: Early Bronze Age Upton Lovell G2a burial. Antiquity 74(284), 271-2.

Sillar, B., 2000. Dung by preference: the choice of fuel as an example of how Andean pottery production is embedded within wider technical, social, and economic practices. Archaeometry 42(1), 43-60.

Singleton, J., 1989. Japanese folkcraft pottery apprenticeship: cultural patterns of an educational institution, in Apprenticeship: From Theory to Method and Back Again, ed. M. Coy. Albany (NY): State University of New York Press, 13-30.

Singleton, J. (ed.), 1998a. Learning in Likely Places: Varieties of Apprenticeship in Japan. Cambridge: Cambridge University Press.

Singleton, J., 1998b. Craft and art education in Mashiko pottery workshops, in Learning in Likely Places: Varieties of Apprenticeship in Japan, ed. J. Singleton. Cambridge: Cambridge University Press, 122-33.

Sofaer, J.L., 2008. Perform Everyday. Brussels: What $>$.

Sofaer, J.R., 2006a. The Body as Material Culture: a Theoretical Osteoarchaeology. Cambridge: Cambridge University Press.

Sofaer, J.R., 2006b. Pots, houses and metal: technological relations at the Bronze Age tell at Százhalombatta, Hungary. Oxford Journal of Archaeology 25(2), 127-47.

Sofaer, J.\& M. Vicze, in prep. Continuity and Change in Life on a Bronze Age Tell: the Late Bronze Age and Middle Bronze Age Koszider Pottery from Százhalombatta, Hungary. Százhalombatta and Gothenburg: Matrica Museum, Swedish Survey (UV) and University of Gothenburg.

Sturt, G., 1923. The Wheelwright's Shop. Cambridge: Cambridge University Press.

Toren, C., 1994. On childhood cognition and social institutions. Man, The Journal of the Royal Anthropological Institute 29, 979-81.

Toren, C., 1999. Mind, Materiality and History: Explorations in Fijian Ethnography. London: Routledge.

Vicze, M., 2001. Dunaújváros-Duna-dűlő, The Early and Middle Bronze Age Cemetery of Dunaújváros-Kosziderpadlás. Unpublished PhD thesis. Eötvös Loránd University Budapest.

Wynne-Jones, S., 2007. It's what you do with it that counts: performed identities on the East African coastal landscape. Journal of Social Archaeology 7(3), 325-45.

\section{Author biographies}

Sandy Budden is a Leverhulme Early Career Research Fellow at the University of Southampton. She is currently using the dynamic relationship between learning strategies and pottery technology to explore the nature of cultural transition from the Late Bronze Age to Early Iron Age in central Europe.

Joanna Sofaer is Senior Lecturer in Archaeology at the University of Southampton and has published widely on European Prehistory and archaeological theory. She is author of The Body as Material Culture (2006), editor of Children and Material Culture (2000), Material Identities (2007) and Biographies and Space (with Dana Arnold) (2008). 